\title{
Economic crisis
}

and political

decision:

words and meaning

Virgínia Henriques Calado

Luís Cunha 


\section{INTRODUCTION}

The relationship between crisis and citizenship is complex and ambiguous. Objectively, a crisis, as deep as the one we experienced recently almost inevitably implies a compression of citizenship rights, even of those that we considered unassailable. This is done by reducing some of the institutional responses usually provided by the State, thereby aggravating unemployment and insolvency. It is true that the idea of citizenship was summoned from positions of power, namely with the call for collective commitment in overcoming the crisis. However, it was a mobilization requirement that cannot be dissociated from the attribution of responsibilities, which are also collective, as was the generic and abusive claim that people had lived above possibilities.

Aware of the multiplicity of approaches to the relationship between crisis and citizenship, let us elucidate the purpose of this text: it is not an analysis of how specific groups of citizens have organized to provide answers to the crisis. What we are looking for is an identification of particular mechanisms - expressed in the construction of narratives and in the language used through which a convincing world view is created and the responses to the crisis are sought to influence the exercise of citizenship. If a crisis context can be seen as leading to specific forms of exercising citizenship, it should also be emphasized that discourses and narratives about it contribute to the definition of specific forms of citizen organization. It is therefore important that we devote particular attention to them. The experience of the crisis creates favourable conditions for the affirmation of models of deconstruction and deciphering that may be relevant to a more enlightened and committed citizenship. In some ways, it is in the debate between a hegemonic narrative, which denies the ideological dimension on which it is based, and the effort to uncover the mechanisms of its construction, that our contribution is situated.

\section{FROM CRISIS TO CRISES: SEGMENTATION AND DISSIMULATION}

This chapter is definitely not a proposal to understand the crisis from the Political economy point of view, nor can we place this input in the sphere of Political philosophy or make it fit into the old or renewed debates of Economic sociology or Economic anthropology, even though its authors are trained anthropologists. The difficulty in accurately placing ourselves arises not only 
from the nature of the object of inquiry but also from the intersection of two epistemological vectors: the attempt to observe it from an effort of disciplinary transversality and the heuristic value that we give to the interstitial spaces within the framework of the debate we aim to initiate.

We will not address the discussion concerning the virtues and possible inadequacies of a model of ordering and organizing knowledge with its core on the strict specialization and the inevitable fragmentation that comes with it. As a replacement for this necessarily long and inevitably displaced discussion, we emphasize that the object we propose to address, at least in the way we conceive it, is particularly dispersed by areas of knowledge which, in some cases, are not even contiguous. From our point of view, therefore, it recommends an integrated gaze inspired by what could be called a general theory of social systems. We do not, obviously, intend to propose something that resembles this, but we still seek an approach based more on dispersion than on specialization, engendered more in a(n) (un)certain cross-fertilization of knowledge than on a narrow respect for disciplinary boundaries.

It is not, of course, only a matter of trying a free exercise of heterodoxy before modestly contributing to a debate which, by its very nature and implications, needs to be as broad as possible. We understand that disciplinary boundaries are not limited to defining knowledge only in favour of a virtuous specialization, but they are also decisive in creating the hierarchy of these fields of knowledge. On the other hand, the dispute concerning legitimate fields of knowledge can operate, and does operate in the case of economics, a disguise effect, which limits and restrains the practical action of agents. To put it in another way, and trying to connect these arguments, we consider specialization not only as a consequence of an operative rationality sustained by the virtues of labour division; it is also the product of the symbolic fights that move across the fields of knowledge and, thus, creator of representations and conceptions of the world that guide social practices.

Before we even enunciate the script we intend to follow, let us begin by considering the nature of the object of search, seeking to point out the way in which it shows itself as elusive, assuming different images, reconfiguring itself, without essential changing. It is important to highlight that the crisis we are talking about, and which we will discuss here, has had different forms of expression, themselves associated with different narratives, as if they were different and disconnected phenomena (Teles 2017, 53-54). It was first named a crisis in financial systems, thus referring to a global financial crisis (2007-08) 
that resulted from the implosion of the us financial market, which had grown speculatively due to the strong flow of foreign capital to that country (Varoufakis 2015). What followed, clearly from 2011 on, was the public debt crisis in the Eurozone, which was therefore given a distinct geographical scope and also a different explanation - that of the imbalance between creditor and debtor countries, with the latter suffering the most penalizing consequences. ${ }^{1}$ From 2013 on and as a result of the reversal of us monetary policy and the loss of market value of many commodities, a third side of the crisis became clear, now affecting emerging countries. ${ }^{2}$ Finally, today: "we are apparently in the fourth act of the crisis" (Teles 2017, 54). This crisis is centred in the developed countries, which have plunged into a long period of low growth, high unemployment, and have come close to deflation in a situation of apparent endless stagnation.

The opinion of economists concerning this issue is not consensual, but this is not what matters to us here. The point that seems most relevant to us is the one concerning the practical effects of this process of fragmentation of a phenomenon that in many ways is seen as indivisible. We argue that this segmentation is neither neutral nor justified by strictly technical criteria, but it depends instead on the adjustment to far-reaching political narratives. This adjustment has decisive implications from the point of view of the measures applied to the resolution of the crisis, since it signifies a change of moral judgment on its causes. ${ }^{3}$ It should also be mentioned that this segmentation of the crisis is already a simplification, as it leaves out the possibility of thinking about this mutant crisis in a longer temporality, just like other dimensions that only seem to escape it. In the long run it is possible to trace back the current

1 A direct relationship can be established between these two acts of crisis: "the crisis has undergone a metamorphosis: what was apparently a financial crisis in 2007-2008 - the banking freeze and the credit crunch - became an explosive political crisis because states were directly involved in solving the financial crisis, with the burden being transferred to states and governments"' (Thompson 2011,38) [our translation].

2 Equally inseparable from the $2007 / 8$ crisis, especially if we see in the slowdown in growth of these countries as a consequence of the collapse of the financial surplus recycling mechanism, as proposed by Varoufakis (2015).

3 If the "crisis of the financial systems" hardly escapes a critical evaluation of the performance of banks and the greed of financial agents, its transmutation into a "public debt crisis" places moral judgment on the reckless behaviour of ordinary citizens - "We lived beyond our means." The "genesis amnesia", pointed out by Bourdieu $(2000,16)$, has a clear illustration here. 
developments to the oil crisis (1973) and to the profound economic, political, and social transformations promoted by Ronald Reagan and Margaret Thatcher's governments (Judt 2010, 99). On the other hand, and concerning a different issue, the refugee crisis as a result of the greater migratory wave and humanitarian crisis that Europe has faced since World War II, or the resurgence of nationalist movements, both have evident connections with global processes (financial, political, and others) that explain economic crises stricto sensu.

In a globalized world like the one we live in - unequally globalized, we already know it, but which has precisely in the financial system one of the highest exponents of globalization (Santos 2001) - it seems inappropriate to split or circumscribe financial crises according to geographical or spatial criteria. The sovereign debts of the southern European countries and the strong decelerating or even halt in the growth rate of the emerging countries cannot be separated from a global macroeconomic framework, which includes phenomena such as the social division of labour, the direction of flows in a global economy, or the unequal power of countries. We should not, however, reduce the proposals for segmentation of the crisis to an error of evaluation or to a desire to simplify it, nor to a deliberate effort to control damages made by those who have an interest in this same control. We argue that we should see in them not a strategy but a condition that tends to be structural: "We are segmented everywhere and in all directions. Man is a segmental animal. Segmentarity belongs to all the strata that compose us" (Deleuze and Guattari $1972,268)$. However, the classical opposition between the segmentary and the centralized is not relevant in this case:

The modern political system is a global, unified and unifying whole, but [this is so] because it implies a set of juxtaposed, overlapping, orderly subsystems in such a way that the analysis of decisions reveals all sorts of separations and partial processes that are not maintained from one to the next without imbalances or displacements. (Deleuze and Guattari 1972, 269)

We can see in this description of the modern model of power a design that fits the way in which the dominant economic theory - let us call it Theory of Rational Action - manages its territory. Crossing the different axes in which power is centred and their branches (political, financial, legal, and even media centres) are located with an instrumental segmentation of the event, which is also language containment, a closing effect is achieved that allows to both 
govern the reading of the past and to predict the future. ${ }^{4}$ Closing means, in this case, a molecular expansion of unified signs, a meaning-producing machine, which curtails the counterpoint, preventing, in the limit, dissent. This closure can be both manifest and sometimes subtle in our everyday experience obvious, for instance, in the recognition as truth of the statement "There Is No Alternative" condensed into the acronym TiNA; more subtle when a neutral judgment is attributed to financial rating agencies, as if this neutrality were derived from the function they perform, and cannot be tainted by the links to actual branches of the financial system. One can see in these examples the molecular expansion of a truth that does not allow any discussion and involves complex devices, which have a formal sedimentation - for instance in the legal sphere - but also informal, clear in the political discourse or in the media space. From this comes, thus, an enclosing of public sphere (Habermas 1962) and the reduction of the exercise of citizenship to innocuous ritual procedures.

Returning to the idea of crisis, we understand that we must see in it simultaneously a singular moment and also the materialization of a cyclical event that is an integral part of how economy works in modern societies. In the first sense, the idea of crisis (re)assumes a meaning that seems to have been lost. Understood as a "decisive moment" (Leone 2016, 11), it would signal a turning point, an end of cycle in its minimalist expression, or, in its maximalist expression, the revolutionary end of an era. ${ }^{5}$ The second sense we proposed is not contradictory when compared to this one, it just implies another focus. Instead of seeing the crisis as a decisive moment, it is a matter of seeing it as an inevitable consequence of the dynamics of a system that needs the crisis to regenerate itself. It is not a question of declaring the existence of a definite intentionality, let alone trying any conspiracy theory (Thompson 2011,43), but the mere replacement of the belief in the virtuous balance generated by

4 The homogenization of a narrative brings us, of course, before the question of agency: to which instance should be attributed the greater responsibility in the production of this narrative? Where should we put the line that separates this production from its homogenization, in order to perceive the dynamics of processes and their agents? Rehearsing an answer to these issues is outside the scope of this work, but here is its signage.

5 In this sense, Castells' reading $(2013,10)$ seems to indicate the minimalist option: "the aftermath [of the crisis] is fundamentally the aftermath of the end of a particular model of speculative capitalism." In the maximalist version we would, of course, be faced with the irrecoverable collapse of the capitalist model. 
the market by the idea that successive imbalances are systemic and the result of structural inequalities between individual agents and collective entities, such as countries. If we put debt at the heart of the capitalist economy (Thompson 2011,33 ), we can see the crisis as the extreme manifestation of the structural imbalance between debtor and creditor (Varoufakis 2015), bringing to life the market, levelling and egalitarian, as an essential fantasy for the health of the capitalist system. ${ }^{6}$ Seen through these lenses, the crisis, any crisis, but also this one in which we still live, acquires another expression, losing neutrality to assume a definite political sense: that of managing inequalities, naturalizing them, and emptying them of their arbitrary contents. The success of this effect depends, as we shall see later, on the effectiveness of the narratives that the model itself demands. Aspects such as persuasion, disguise, and even the use of forms of external intervention (Troika) are consistent with this narrative, sustaining and reinforcing it. Grant (2012), discussing the legitimacy of the use of incentives, such as IMF loans, argues precisely that these, like persuasion or coercion, are forms of exercising power that allow the manipulation of individuals through political games.

It is to this exercise of making sense that we should report the theoretical and practical work of segmenting the crisis. Whether considered at the level of diagnosis or therapy, this segmentation, like any other, can be reported in an apparently neutral way to the complex exercise of drawing boundaries and operating distinctions, that is, to an act of ordering that is simultaneously indispensable and arbitrary (Cunha 2007). Inevitability stems from the need to give a recognizable meaning to what would otherwise be a chaotic succession of events. Arbitrariness arises from the definition of the criteria of ordering, of the place where the frontier is placed and legitimized, that is, of the division of the world that is inherent to the act of drawing boundaries (Bourdieu 1989). The arbitrary nature of the division is dissimulated; from the very beginning thanks to the auctoritas of who divides, which refers to the enunciation and to the acts that create meaning and govern the legitimate order of the world. If we consider specifically the economic order, which has, as we shall see, the ambition of becoming a global order, we will realize that the procedures added to this device are multiple, complex, and widespread. For our part, although without the ambition of being exhaustive, we will focus our analysis on the

6 The centrality of debt is discussed by Caillé $(2002,248)$ in an even more fundamental sense, which is the hypothesis of debt being constitutive of the subject and guarantor of social perenniality. 
mechanisms that produce a convincing narrative, summoning, as an example, the political discourse, specifically by analysing the speeches of the prime ministers in the framework of the Debates on the State of the Nation over ten years (2008-17).

The idea of narrative is understood here as a statement composed by expressive content, that is, "A method of recapitulating past experience that consists in matching a sequence of events (supposedly real) to an identical sequence of verbal propositions" (Labov 1978, 295). The discourse seems a set of statements that cannot be separated from its setting of production (Reis and Lopes 2002, 110). Thus, the meaning that derives from discourse and is expressed in words, expressions, and prepositions, is inseparable from sociohistorical processes and from the ideological placement of agents.

The roadmap for what remains of this paper can now be drawn. We have argued that the process of segmentation of the crisis into sectoral crises is not able to be reduced to a possible technical justification, implying, on the contrary, the management of a narrative that not only orders temporality but also affects the meaning of past actions and the strategy for future actions. In the next steps of this work we will try to open the analysis beyond the technical and also symbolic process of crisis segmentation. We will focus on the sphere of language, summoning, at first, some of the central narratives of formalist economic theory, and then focusing on the contemporary modalities of word management through the use of an almost newspeak in the Orwellian sense of the term. Finally, we will conclude by addressing processes of enunciation recorded in political discourse, choosing, in this case, an analysis that we have taken as illustrative, since it focuses on a singular moment - Debates on the State of the Nation - and on the expression of a single voice, that of the acting Prime Minister.

We consider that political discourse does, in its own way, what science does as well: it classifies and orders, it intersects things and words in order to create rhetorical effects that can become generators of meaning and truth, giving expression to a world view according to specific knowledge and beliefs. ${ }^{7}$ We will consider political discourse directly in its expression of power, a power to make see and make believe (Bourdieu 1989), which generates a meaning of the world, which, when elaborated in a competent way (widely recognized as legitimate) can correspond to a vision of reality that seems objective and 
irrefutable. If the high technicity of Political Economy is a field to experts only, the possibility of applying far-reaching measures to the economy belongs to the State and to those who rule it. Two orders of meaning are thus articulated, into which we will look. On the one hand, one deriving from the competence recognized in the economics experts; on the other hand, another one that is based on the way in which political discourse leans upon and reinforces ideologies (Mannheim 1960) that are widespread in social space.

\section{OLD FABLES AND NEW TALES:}

\section{PERSISTENCE AND RENEWAL OF NARRATIVES}

In a work whose greatest aim was dissemination, Vitor Bento summons morals to help explain economics:

Economics, as a study of reality or, more accurately, of human behaviour related to economic activity, is a positive science and, as such, a science (practically) independent of moral considerations. But economy, as a human activity, always works in moral contexts.

(Bento 2011, 10)

The distinction pointed out by Vitor Bento is almost reduced to irrelevance if we believe that all human activity is economic, that is, if we reduce society to the market. The ambition to be a positive science and the inevitability of being a social science could lead Political Economy to an unmanageable field, which, as we know, does not happen. On the contrary, economists move on clearly defined, monitored, rationalized, and predictable grounds. How do you get this effect? It is often done by placing morality at the service of economics, that is, by making it the basis of positive science, by establishing a connection between human nature and economic behaviour. Fables and metaphors have served this purpose, so it is worthwhile considering here, even briefly, something that can be seen as belonging to the matrix narratives of Political Economics.

In 1714 Bernard de Mandeville published The Fable of the Bees, or: Private Vices, Public Benefits that would become famous in the core arguments developed by Political Economics. About half a century later, Adam Smith published his most famous work, An Inquiry into the Nature and Causes of the Wealth of Nations (1776), which is an expressive example to account for natural economic behaviour: 
It is not from the benevolence of the butcher, the brewer, or the baker that we expect our dinner, but from their regard to their own interest. We address ourselves, not to their humanity but to their self-love, and never talk to them of our own necessities but of their advantages. (Smith 1776, 95)

These two narratives converge in the idea that it is private interest that leads to the proper operation of both society and economy, but in no case the dispensability of ethics and morality is affirmed. Mandeville is suspicious of virtue, seeing behind it selfishness - for instance, when carrying out charitable acts, one finds personal satisfaction in them (Brito 2014). In his case, the debate focuses not on the grounds of morality but on denouncing hypocrisy, which he does with a sharp cynicism. As for Adam Smith, it would be extremely reductive to see him as a defender of the subordination of morality and ethics to strict economic rationality. Not only for his Theory of Moral Sentiments (1759), but for the fact that his work could and should be seen as an attempt to build a social and moral science, far beyond the framework of nineteenth-century political economy (Swedberg 1994, 44). ${ }^{8}$ Contrary to this perspective, the course taken by Political Economics meant distancing itself from the uncertainty of a moral social science, favouring the development of a model that should be capable of replacing uncertainty. What we are interested in discussing at this point is not the relevance of these authors to economic theory, but rather perceiving the genesis of the narrative that founded and still supports economic liberalism. Basic principles, such as rational choice, peer competition, mobilizing ambition, meritocracy, or even free enterprise, are found in Mandeville and Adam Smith, but they also have other links to the world of thought and science, such as Charles Darwin and the idea of natural selection, or the primitive accumulation of capital behaviour illustrated by Robinson Crusoe in the well-known novel by Daniel Defoe, just to mention two famous and different references.

Perhaps it is more appropriate to think of narrative threads that intertwine and unlace themselves, getting lost only to be rediscovered later on, in some cases obeying to remarkable processes of resignification. For instance, between the mobilizing ambition of the founders and the greed that their heirs place on the functioning of Wall Street, the heart of the System (Varoufakis 2015, 35),

8 "The explanation of human nature, therefore, which takes self-love from every feeling and affection (...) comes, in my opinion, from a confused and false interpretation of the empathy system" (Smith $1759,554)$. 
goes a step too far. On the other hand, the narrative today hegemonic has already had a subordinate expression. It will suffice to consider the consolidation of a counter-narrative following the Great Depression of the late 1920s. The Keynesian model, by focusing the initiative on the State, making it an active regulator of economic practices, proposes another line of thought, another narrative, which became prevalent in the following decades, losing its momentum only in the 1970 s.

The return to a homo economicus, which is a matrix in many aspects, has been approached in several ways and by different authors, with distinct highlights given to this recovery. The withdrawal from the fixed exchange system defined in Breton Woods; the huge increase in the price of oil imposed by the producing countries; the growing financial difficulties in the USA following the conflicts in Korea and Vietnam; the ascent to power in the USA and UK of two strong and mobilizing liberals, Ronald Reagan and Margaret Thatcher; the growing demographic imbalances endangering the funding of the welfare state; the obviously growing weakness of planned economies in eastern Europe: these are just a few factors we could refer to here. It is difficult to determine whether these and other historical moments are triggered by crises or whether they are crises generators themselves. One of the faces of this difficulty arises from the more or less spontaneous association of the crisis with a situation of abnormality or exceptionality, instead of considering it as an intrinsic part of the economic cycle, thus replacing dysfunction by systematicity. On the other hand, it is impossible to equalize all crises, insofar as some determine real turning points. Understanding the depth of a crisis involves considering the density of the narratives that explain it and underpin the therapy that applies to it. It is in this sense that the analysis of political discourse gains importance as we shall later see and justify. Before we get there, however, it is important to return to the issue of narrative construction in order to better understand its solidity and its weaknesses.

\section{FROM WORDS TO MEANING: OLD AND NEW WAYS OF SAYING}

Putting aside the ambition to call on the currents and authors who over the years have been doing the history of Political Economy, we aim to argue that Political Economy has been structured around a basic narrative, which, although undergoing adjustments and reformulations, maintains an identity 
and a project that stems from its umbilical relationship with the capitalist mode of production. We sought to show how the founding nucleus of the main narrative was constituted and which were its constitutive elements - discourse on human nature based on individualism and belief in a virtuous balance based on the idea of competitive market - a wide range narrative that never broke up with its founding nucleus, having, nonetheless, suffered successive readjustments. To look at this narrative in time implies considering the long and complex process that has brought us to the present and which also confronts us with the reasons for the success of the Theory of Rational Action as an explanatory discourse of economic things and, more broadly, of human action. ${ }^{9}$ In order to understand this success, it is important to highlight the connection of three effects: the idea of rigour and scientificity created; the restriction of access to their field of knowledge by those who are not accredited; the ability to become indispensable to political power.

The first of these effects received a contribution from the supposed predictive capacity of economic science, assuming a reliability that can only be based on the knowledge of human nature, as it is revealed in the foundational narrativeto which wehavejust alluded. The reduction of human rationality to the homo economicus, a character marked by competitiveness, by the maximization of profit and, ultimately, by selfishness, topics seen as invigorating of economic activity, allows us to look at economics as a set of mechanical forces tending toward balance. Discovering this mechanics would only be a question of finding the technical instruments that are capable of responding to the ambition to forecast and anticipate the natural development of economics. Mathematics then emerged as a basis for the creation of these instruments, providing technical support, through increasingly complex models, to macroeconomic forecasts. The second aspect arises, at least in part, from this mathematizing. The growing technicality, at the same time as it requires peer recognition, prohibits the field to non-specialists, making Political Economy a unique case in the universe of social sciences (Swedberg 2006, 77). We find here, in some way, a successful alliance between Political Economy and Statistics, both competing for the most perfect government in the 
world. ${ }^{10}$ The last aspect is precisely this one, the strong overlap between political power and the vision of economic things proposed by Political Economy. Looking at contemporaneity, we also see a somehow unexpected effect of this strong articulation: the Prince's Counsellor, a status that has, in fact, long been in the hands of economists, threatens to take the place of the Prince himself. The divorce between power and politics eventually translated into "statism without a State" (Bordoni and Bauman 2016, 24), which is largely a consequence of the process triggered by the projection of Political Economy as the main explanatory (and prospective) science of social activity. The market regulated by the pursuit of self-interest gives way to a voracious machine, which, in the name of effectiveness, requires the State to abdicate the possibility of regulation, both in the financial sector and in relation to social protection mechanisms; whether they are direct, such as the Basic Social Income, or indirect, such as protectionism arising from labour legislation.

These three conditions for success are not enough by themselves. They imply the existence of an enormous performativity of economic theory, which, at the same time that it shapes the practices, also guarantees that the narrative adjusts to the historical circumstances that determine the transformation of the economy. In fact, the persistence of a capitalist model of production does not prevent the significant changes that have been under way since the eighteenth century and that can be measured or traced back in various levels. Thomas Piketty (2014), for instance, shows us the transformation of the distribution of national capital, especially in France and England, pointing to the replacement of agricultural income by that generated by urban properties, as well as the abrupt reduction of income from foreign capital that followed decolonization. Other authors record and highlight different indicators of this historical transformation in the way capitalist economy works. Today we live in the era of informational capitalism (Castells 2013, 10), we anticipate, or wish, a cognitive capitalism (Abreu 2017, 229), we witness the accelerated process of funding the economy (Teles 2017,63) and also the reconfiguration of the international division of labour as a result of the deepening of globalization (Santos 2011). The adjustment between economic theory (expert competence) and economic narrative (disseminated and consumed in the social space) implies language

10 Considering the history of statistics, we see how it became essential for the legitimization of political action: "statistics presented itself as an essential instrument for rationalizing the conduction of human affairs" (Desrosières 2000, 122). 
effects, including semantic transformations, a phenomenon that has become visible in the last decades. Without the ambition of a systematic approach, we will consider some examples that we find relevant to what we have called above newspeak. ${ }^{11}$

As background we can have a mutation of meaning that tends to transform into regular and constant what was considered singular and circumstantial. We talked about the crisis pointing to the segmentation of its contents and, consequently, to the difficulty in distinguishing between crisis and non-crisis. Let us note now that, taken in this sense, the crisis is inseparable from the idea of reform. In this case, too, it evolved from a strict sense, that of reform as a detachable event, marked by an improvement or renewal into an open and reasonably imprecise meaning, with some reforms appearing not as improvements but objectively as setbacks. ${ }^{12}$ As with the idea of crisis, the idea of reform no longer corresponds to an exceptional moment, so that it seems a permanent intervention, which regulates the adjustment of social life and economic practice to macroeconomic theorization. Seen in this light, the reformist proposals refer to the idea of metanoia, either in the (almost) religious sense of conversion or in the sense of a reform of the psyche, a change that begins by being mental and then becomes management of action. We also have to consider the idea of adjustment, one of the pivotal concepts of this newspeak learnt from economics. Stripped from the idea of adjustment and conciliation between parties, the word acquires in its new use by economics a somewhat euphemistic sense, since it fits deep transformations in the semantic memory of conciliatory adjustment.

Emphasizing, once again, that our intention is more to illustrate than to systematize, we summon the processes of transferring specialized language, born among scholars and academics, to the public space, and its transformation into everyday language. Sovereign debt, swaps, but also derivatives market, among others, have become expressions of common usage, with more or less accuracy in their use. The centrality assumed by Management explains another type of contamination and, in this case, also of vocabulary substitution,

11 Inspiration for this comes from Orwell, but can also refer to other sources, for example the new hitlerian language (Faye 1973,34), or any other attempt to mobilize language in search of a determined political effect, that of totalitarianism.

12 We do not use the notions of advancement and regression as an expression of any historical determinism. We only emphasize that if we consider social space as a place of dispute we must see the current reformism as a marker of the reversal of social achievements (for example, in labour rights). 
words such as CEO, coaching, benchmarking, outsourcing, and stakeholders are examples of that kind of vocabulary. ${ }^{13}$ These innovations, valued in the name of modernity or the need to respond to the demands of globalization, are concomitant with a set of determining transformations, at the level of both practices and representations. An example that accounts for the effect of disguise is the transformation of the worker into a collaborator, to put it in another way, the ability to hide what one does not want to show, maintaining a minimum level of acceptability. ${ }^{14}$ This effect is achieved thanks to the conjunction, operated by language, of a supposed equalization of the subjects (we are all collaborators) and an update of concepts, seen as necessary for the modernization of the country and the economy. In this way, the effective devaluation of the labour factor becomes a potential valuing resulting from labour flexibility; the loss of the guarantees contained in collective labour agreements is distorted in the name of the virtues of competition and personal commitment; the inequalities inherent to the system are reconfigured as the result of both the workers' capacity for work and differentiated effort.

We can see the foundational narrative of Political Economy and narratives derived from it through the concepts with which they operate, with the words they use, and with the recognition they imply, as points of encounter and conciliation between a dominant and tendentiously hegemonic theory and the "economic practices and ordinary forms of calculation". ${ }^{15}$ The divergence between these two operational levels is solved, precisely, by language, which allows us to think economic science and the categories with which it operates as ahistorical (Bourdieu 2000). Transposed into the arena of public debate, reconfigured words help to make sense of the social processes in which agents are involved. This is also done by suggesting a simplification of economic language, which creates the illusion that it is accessible to anyone, and at the same time resorting to a complexification that prohibits access to nonspecialists. These two effects, which are contradictory only in appearance,

13 On the importance of "management professionals" in the transformations since the 1970s, see Cardoso $(2013,52)$.

14 Faye $(1973,174)$, discusses the idea of acceptability in relation to those from which one cannot hide what one intends to hide. Bourdieu $(1982,75)$ discusses the social conditions of acceptability in the level of language.

15 We use here the title chosen by Florence Weber (2002) for an article that deals with the real way the economy works, which in many aspects stands out from the "utilitarian theory". In his early works, Bourdieu (2000) notes and highlights these discrepancies. 
should be seen as complementary: if the first effect gives rise to the idea of a unified field for all, which equalizes all players within the market, assuming that they are equally equipped for the competition generated there, the second effect is activated whenever one goes to the level of explanation and definition of economic policies, guaranteeing a control of the processes - also here disguising the performativity of the decisions (deregulation of labour, loss of state power, etc.) under the cover of newspeak, as formulated by theory. ${ }^{16}$ Political discourse is undoubtedly a part of this complex mechanism that generates meaning, and we will address it to conclude this paper.

\section{THE POLITICAL DISCOURSE: METAPHORS AND REFLECTIONS}

The debates on the State of the Nation happen in the middle of the calendar year (July), preceding the vacation period and consequent slowing down of political activity. They constitute an opportunity for retrospective, which the Government uses to justify its action and present new measures, and which the Opposition uses to create political difficulties for the Government, denouncing failures or shortcomings. There are a lot of games, staging, and dissimulation, highlighting the positive or negative colours of political acts and statistical indicators, highlighting or devaluing external factors, etc. Although it is an important moment from the point of view of political confrontation, we opted, on this occasion, to stick to the Prime Minister's speech. This is a debatable option, but with it we sought to highlight the political act as a combination between discourse and power to apply measures. ${ }^{17}$ Considered in a relatively long time, we can see these discourses as an illustration of the possibility for a differentiated reading of the crisis, but above all of the strategies of rhetorical construction of arguments that justify real political actions, including manipulative strategies, which both announce measures of rupture as continuous and, in opposition, claim to be different, changing nothing concerning the past outcomes of contestation. Taking into account the

16 The availability in the current banking market of complex financial products, and their acquisition without adequate knowledge of their characteristics, generated financial losses to many thousands of Portuguese citizens, who argued with their banking institutions, in favour of their part as savers and not investors.

17 For an analysis that also draws on Prime Ministers' speeches and interviews with members of the Governments in office during the Troika period, see Moury and Standring (2017). 
objectives of this work, we consider the period in which the crisis is stated, the period marked by external intervention and the current period. A ten year span (2008-2017) is thus defined, which includes three legislatures and three prime ministers - three speeches by José Sócrates (2008/2009/2010), four by Passos Coelho (2012/2013/2014/2015), and two by António Costa (2016/2017).

Corresponding to expectations, the crisis is clearly present in the nine discourses we analysed. ${ }^{18}$ It begins bybeing considered in a limited and restricted way by Sócrates who, in 2008, summons it to explain Portugal's difficulties in the foreign market (the increase in the price of oil and rise of value of the euro), and then becomes central in his last speech as prime minister, and in all the speeches of Passos Coelho, and relatively subtle in discourses by António Costa. Leaving aside the explanation of the crisis for now, all discourses converge into the idea that "the worst is now over", that is, they all announce turning points as a result of the policies they are using. Somehow we can see here a central aspect to the narrative strategy of discourses: the systematic recurrence to a set of simple binary oppositions, in this case between crisis and overcoming, but which has other expressions - government/opposition; active/passive; change/permanence, irresponsible investment/budget discipline, etc. These oppositions are structural in the sense that they define significations in an expressive way, signalling what must be done in opposition to what others want: doing differently or preventing what is necessary. In some cases, the rhetoric used seems to depend less on ideological factors than on the fact of being in government or in opposition. This is what happens with the accusation of being too passive in the face of the crisis or of favouring the permanence at the expense of the necessary change. Even ideologically fracturing themes, such as public investment, admit some ambiguity, depending on the lived moment. Thus, at the beginning of the crisis, in 2008, José Sócrates pointed out to the opposition, stating: "We have all felt, in practice, the deeply negative effects of the theory that the country would not supposedly have money for anything and would have to give up any investment in its future". This "theory", which he later states as "nefarious", is not properly confirmed by Passos Coelho, who chooses to associate the risks inherent in the fiscal consolidation plan with a state-held restraint role: "the expenses of the public administration sector and of state's business sector, are being reduced at a considerable pace". In the speech of 2016, António Costa proposes to "turn the page of austerity", reassigning importance to public 
investment, through the announcement of new Programmes - National Fund for Urban Rehabilitation and Blue Fund, dedicated to the economy of the sea - and promising to raise limitations to municipal investment.

Beyond crisis, there is another important feature unifying speeches, the idea of reform. We have seen how this word has become central to the economists' vocabulary, and we find here an evident approximation between these two universes. It is, however, a rhetorical centrality, since it is too imprecise and vague what the proclaimed reformism refers to. In Sócrates, reform is inseparable from modernization and it reports, especially in 2008 , to technological development - renewable energies or the Technological Plan for Education. In the following years, he gave in with the accentuation of the crisis, speaking of a "reformist agenda" applied to Social Security (2009), without ever failing to say that he advocates a "value-oriented reform" (2010). Passos Coelho gives another meaning to reform: his purpose is to "build a new economy: more competitive, more open, more democratic" (2013). We are, in this case, closer to what can be called the liberal agenda, with reformism emerging as an instrument of structural transformation of the economy. If Sócrates placed the State at the centre of the reformist action, Coelho sees reform in the retreat of the state. As for Costa, he proposes (2016) a National Reform Programme with six fundamental pillars, highlighting education, innovation, and modernization of the State. We can see the recovery of qualification and technology that Sócrates insisted upon, but it seems more vital to us the replacement of a macroeconomic reformism by a more nuanced and convergent solution that bears the idea of "turning the page of austerity" (2016).

The ideas of modernization and progress are also recurrent, thus suggesting a structural function, exactly that of pointing out, once again, the counterpoint between what exists, and is seen as an unwanted inheritance of those who have abandoned power, and what they promise to achieve, in the condition that it is always to attain consensus, or at least a responsible opposition, which does not follow a "bottom-up culture" - a term used by Sócrates in 2008. Modernization is always seen as indispensable to good governance, signalling a necessary path to the desired approach to some of our European partners. Here, too, convergence is somewhat misleading, since at least two different directions are defined around the same word. On the one hand, modernization through qualification, which implies betting on education and on the maintenance of a strong Social State; on the other hand, modernization as a design of the economy, which refers to the demand for greater liberalization and reduction 
of the weight of the State. Sócrates is in the first case and Coelho in the second, of course, although this distinction is not clearly shown, since both resort, perhaps in a rhetorical way, to solutions other than those they seem to prioritize: Sócrates promises "budget consolidation" (2010) and Coelho "the real qualification of every Portuguese person" (2012).

The use of strongly convergent narrative strategies makes it difficult to find in these discourses clear points of ideological fracture. Nevertheless, while in the discourses of Sócrates and Costa one perceives a political position within the social-democratic tradition, in Coelho's discourses the emphasis is always placed on the false/true dichotomy, being ideology a part of the first term and reality a consequence of the second. The theme of his first speech (2012) seems to be a "clarifying moment", which means that the crisis has led the country to a situation that results from giving in to ideologies and it is necessary to rediscover the path by living according to reality. This understanding supports the proclamation that there is no alternative, and there is therefore only one path which, because it is the only one, reveals itself to be stripped of ideology - "ideology" is a "booklet", a "distraction", as he states in the 2015 debate. In Passos Coelho's speeches, the idea of truth opposes not only what is false, but also what is illusory and unreasonable. This is why Passos Coelho opposes policies that defend the hope in "more or less miraculous events" (2012), excluding "magical solutions" (2013). In this same discourse he makes this very structuring distinction of his thought very clear: "It is the duty of all political agents not to confuse the reality of the country with the strict world of politics and the media agenda. It is mainly with Costa that this inevitability (TINA) is deconstructed through discourse. In his speech of 2017 he declares: "Yes, there was an alternative!", and this alternative, if not ideologically assumed, is at least politically valued because it translates itself into a "climate of social peace and institutional normality." Looking at the question from the point of view of economic theory, the clearest confrontation is between Sócrates and Coelho. The discussion about what triggered the crisis helps us to realize the differences between them. While recognizing external factors, Coelho emphasizes the guilt of those who ruled before him, yielding to an easy way out and disregarding rigour. Thus, he gets closer to a neoliberal vision, apparent in the defence of an open economy, in the orientation of education to respond to the market or in the proposals of reform for the State, centred in the reduction of public expense. Sócrates focuses his 2009 speech on the idea that the crisis has an external origin, exempting the country from direct responsibilities and 
also the political/ideological course that had been followed: "it was not the intervention of the State, nor was it the social state that provoked the crisis!" (2010). The fault lies within the deregulation of financial markets and, in the same speech, he also argues that "poverty and inequality are not fought with any kind of 'invisible hand"'.

Sócrates' censorship of the belief in an invisible hand that governs the economy infallibly provides proper completion to this paper because we see in it the strength of the foundational narrative of Political Economy, root of words and beliefs that are rewritten and persist, thus guiding collective action and the decisions of those who govern. But the invisible hand is also a good metaphor for that which hinders a more active participation of citizens in the polis. We know that this is more implicit than explicit in our writing, but refusing to circumscribe the understanding of the crisis to the restricted circle of authorized specialists, who reduce it to a technicity that ultimately refers to the ungovernable mechanics of an invisible hand, is to diminish democracy and open the way to dangerous motivations.

\section{CONCLUSION}

We have evoked the complexity inherent in the persistence of a foundational narrative as well as the different analytical levels and articulations that need to be used to deepen the debates that we have only touched on in this text. This was very much to look for the signs and language resources that allow the political game and the permanence of certain ideas. We began by stressing how the segmentation of the crisis (crisis in financial systems, public debt crisis in the Eurozone, crisis in emerging countries, crisis of low growth in developed countries) is a form of dissociation that does not encourage an integrated look at the crisis, as a complex phenomenon resulting from the connection of these different segments. Fragmentation, simplification, and recurrence introduce an effect of banalization of the crisis, thus making it possible to be adjusted and manipulated by different political narratives. Second, we emphasized the importance of Political Economy and of the Rational action theory (rational choice, individualism, virtuous balance of the competitive market...) in constructing the arguments for explaining the crisis. It was possible to highlight that at the same time sophistication in the tools of calculation and analysis was produced from the Economy, with closing effects to the 
non-experts, a newspeak and a simplification of language was introduced in order to allow the words that gave sense to social processes. The crisis could thus become a pretext for managing social inequalities. Finally, we sought to illustrate through political speeches how narratives of political affirmation were constructed, highlighting how the notions of crisis and reform but also of adjustment, ideology, and reality were mobilized to produce decisive effects in the sense that is attributed to practices and representations that govern the world. The discursive dynamics allowed us to observe the variable role of a more ideological thought, which is affirmed or faded according to the moment of the political cycle, that is, as it is in the opposition or in the government. We have followed some narrative threads of a complex plot and, although we left out many others, we realize the importance of what is said, what is feigned to be said and, mostly, what is not uttered. It is by linking these ties, paying attention to words and silence, that the community and citizen's participation may be strengthened.

\section{॥ ACKNOWLEDGEMENTS}

This chapter was translated with the financial support of FCT through the strategic project UID/sOC/50013/2013.

Virgínia Henriques Calado wishes to acknowledge funding received from the Portuguese Foundation for Science and Technology (FCT), within the framework of a post-doctoral project (FCT/SFRH/BPD/97532/2013.

VIRGÍNIA HENRIQUES CALADO

Instituto de Ciências Sociais, Universidade de Lisboa

Av. Prof. Aníbal Bettencourt 9-1600-036 Lisboa, Portugal

vmcalado@ics.ulisboa.pt

orcid.org/oooo-0002-5292-2440

LUÍS CUNHA

CRIA, Universidade do Minho

lmcunha@ics.uminho.pt

orcid.org/oooo-0002-9940-9265 


\section{$\S$ REFERENCES}

ABreu, A. 2017. "Histórias do nosso futuro". In AAVv Economia com Todos. Lisbon: Relógio d'Água, 223-236.

assembleia DA República. 2008 to 2017. "Discursos do Estado da Nação". Diário da Assembleia da República, I série.

Bento, V. 2011. Economia, Moral e Política. Lisbon: Fundação Manuel dos Santos.

Bordoni, C., Z. Bauman. 2016. Estado de Crise. Lisbon: Relógio d’Água.

Bourdieu, P. 1982. Ce que parler veut dire. L'économie des échanges linguistiques. Paris:

Fayard.

BOURDIEU, P. 1989. "A identidade e a representação. Elementos para uma reflexão crítica

sobre a ideia de região". In O Poder Simbólico. Lisbon: Difel, 107-132.

Bourdieu, P. 2000. Les structures sociales de l'économie. Paris: Seuil.

BRITO, A. 2014. "Bernard Mandeville e as escolas de caridade". É: Revista Ética e Filosofia

Política, XVII (1): 24-33.

CAILlÉ, A. 2002. “Quelle dette de vie?”. L'Homme, 162 (2): 243-254.

CASTELLS, M. 2011. "A crise global não global e as culturas económicas alternativas". In Aftermath. As Culturas Económicas da Crise em Debate, eds. G. Cardoso, et al. Lisbon: Mundos Sociais, 5-27.

CARdoso, G. 2011. "A falência do interesse próprio e o poder da pertença". In Aftermath. As

Culturas Económicas da Crise em Debate, eds. G. Cardoso, et al. Lisbon: Mundos Sociais, 47-67.

Cunha, L. 2007. "Frontera". In Diccionario de Relaciones Interculturales. Diversidad y Globalización, orgs. G. Barañano, et al. Madrid: Editorial Complutense, 147-157.

Deleuze, G., F. Guattari. 1972. Mil Planaltos. Capitalismo e Esquizofrenia 2. Lisbon: Assírio \& Alvim.

DESROSIÈres, A. 2000. "L' histoire de la statistique comme genre: style d'écriture et usages sociaux”. Genèses, 39 (2): 121-137.

FAYE, J. P. 1973. La critique du langage et son économie. Paris: Éditions Galilée.

FOUCAUlt, M. 1971. L'ordre du discours. Paris: Gallimard.

GRANT, R. 2012. Strings Attached: Untangling the Ethics of Incentives. Princeton and Oxford: Princeton University Press.

Habermas, J. 1962. Mudança Estrutural da Esfera Pública. Rio de Janeiro: Tempo Universitário. JUDT, T. 2010. Um Tratado Sobre os Nossos Atuais Descontentamentos. Lisbon: Edições 70.

LABov, W. 1978. Le parler ordinaire. La langue dans les ghettos noires des états-unis, vol. 1. Paris: Editions de Minuit.

LeOne, C. 2016. Crise e Crises em Portugal. Lisbon: Fundação Manuel dos Santos.

mannheim, K. 1960. Ideology and Utopia. An Introduction to the Sociology of Knowledge. London: Houtledge \& Kegan Paul.

MOURY, C., A. Standring. 2017. “'Going beyond the Troika': power and discourse in Portuguese austerity politics”. European Journal of Political Research, 56 (3): 660-679.

PIKeTty, T. 2014. O Capital no Século XXI. Lisbon: Temas \& Debates.

REIS, C., A. C. Lopes. 2002. Dicionário de Narratologia. Coimbra: Almedina.

SAntos, B. S. 2001. "Os processos de globalização". In Globalização. Fatalidade ou Utopia?, org. B. S. Santos. Porto: Afrontamento, 31-106.

SMith, A. 1759. La teoría de los sentimientos morales. Madrid: Alianza Editorial. 
Smith, A. 1776. Inquérito Sobre a Natureza e a Causa da Riqueza das Nações, vol. 1. Lisbon: Fundação Calouste Gulbenkian.

SWedberg, R. 1994. Une histoire de la sociologie économique. Paris: Desclée de Brouwer.

TELES, N. 2017. "Estagnação e financeirização". In Economia Com Todos. Lisbon: Relógio d’Água, 53-69.

Thompson, J. 2013. "A metamorfose de uma crise financeira, política e social". In Aftermath.

As Culturas Económicas da Crise em Debate, eds. G. Cardoso, et al. Lisbon: Mundos Sociais, 29-45.

VAroufakis, Y. 2015. O Minotauro Global. Lisbon: Bertrand Editora.

Weber, F. 2002. "Práticas económicas e formas de cálculo", Mana, 8 (2): 151-182. 